\title{
Semicytherura Wagner: its inner lamella and its close allies
}

\author{
ROBIN WHATLEY ${ }^{1, *} \&$ GABRIELA CUSMINSKY ${ }^{2}$ \\ ${ }^{1}$ Department of Geology, Institute of Earth Studies, University of Wales, Aberystwyth, Cardiganshire SY23 3DB, UK \\ ${ }^{2}$ Centro Regional Universitario Bariloche/INIBIOMA CONICET, Quintral No 1250/, 8400 San Carlos de Bariloche, Pcia. de Rio Negro, \\ Argentina \\ *Corresponding author (e-mail: gcusmins@crub.uncoma.edu.ar)
}

\begin{abstract}
The genus Semicytherura Wagner differs from all other members of the Cytherurinae in the nature and course of its inner margin/line of concrescence. The inner lamella is very wide anteriorly, while posteriorly the inner margin extends anteriorly almost to the position of the closing muscles. However, two species examined by the authors, Semicytherura clavata (Brady, 1880) and Semicytherura contraria Zhao \& Whatley, 1989, from the SW Atlantic and SE Asia respectively are shown to exhibit this characteristic feature only in the male. In the female of both these species, while the anterior inner lamella is identical to that of the male, posteriorly their inner margins parallel the posterior margin. Similar sex-linkage was show in the genus Angulicytherura which is probably closer to Cytherura than Semicytherura, with a narrow and vestibulate inner lamella. J. Micropalaeontol. 29(1): 1-4, May 2010.
\end{abstract}

KEYWORDS: Ostracoda, systematic, Semicytherura, inner lamella, sexual dimorphism

\section{INTRODUCTION}

The cytheroidean ostracod Family Cytheruridae are an important marine and euryhaline group, ranging from the late Permian to Recent. They are characteristically small, fairly diverse generically but very diverse specifically. Whatley \& Boomer (2000) considered their early (mainly Triassic and Lower Jurassic) evolution but the post Lower Jurassic members of the group, and especially the subfamily Cytherurinae, are in need of revision. This exercise is being undertaken by the senior author as part of the revision of the Treatise on Invertebrate Palaeontology, Part Q, Arthropoda 3, Crustacea, Ostracoda. During the course of this work, a number of interesting anomalies have arisen, and one of these is the subject of the present paper.

\section{THE CYTHERURA/SEMICYTHERURA COMPLEX}

In introducing their new genus Angulicytherura, Schornikov \& Dolgov (1995) discussed relationships within this complex. They demonstrated that the two genera Cytherura Sars, 1866 and Semicytherura Wagner, 1957, were remarkable for the large number of species attributed to them, 238 and 232 respectively (data from Kempf 1986a, b, 1987, 1988, 1995, 1996).

Wagner (1957) distinguished his new genus Semicytherura from Cytherura on the following hard part carapace criteria. Semicytherura has a merodont hinge in which the distal extremities of the median element are crenulated; these are smooth in Cytherura. Also, while the fused zone in Cytherura is relatively narrow and the inner margin/line of concrescence are subparallel to the outer margin, in Semicytherura, the fused zone is much wider anteriorly and especially posteriorly, where it extends some distance anteriorly into the interior of the valve; in some species almost to the position of the adductor muscles. In Semicytherura not only are the courses of the outer margin and the inner margin/line of concrescence very divergent, but the radial pore canals are more abundant, often more complex, longer and more sinuous than in Cytherura and with a larger component of false canals. Both genera, however, are avestibulate.

Many fossil and Recent species attributed to Cytherura have subsequently been placed in Semicytherura, particularly on the grounds of their inner lamellae, and others have been accommodated in such cytherurine genera as Microcytherura Müller, 1894, Hemicytherura Elofson, 1941, Kangarina Coryell \& Fields, 1937, Howeina Hanai, 1957, Levocythere Schornikov, 1969, Procytherura Whatley, 1970 and Angulicytherura Schornikov \& Dolgov, 1995. However, many fossil taxa attributed to Cytherura are known only from their external shell morphology and are almost certainly members of other genera.

Valid species of Cytherura are all rather similar in shape and ornament and have smooth to punctate or delicately reticulate carapace ornament. Semicytherura, on the other hand, varies very considerably in both its shape and outline and, in its ornamentation, ranges from smooth to strongly costate, from punctate to tuberculate. This is shown well by authors, such as Barbieto-González (1971), who illustrated a large number of Recent species of very diverse morphology from around the Greek island of Naxos. Van Morkhoven (1963, p. 349), suggests that 'A detailed study of the rather variable group of species now placed in Semicytherura would probably result in subdivision of the genus into subgenera'. Despite the passage of 45 years, thankfully this has not happened, although Schornikov \& Dolgov (1995, p. 24) seem to advocate such a procedure, and we have been spared a plethora of irrelevant and unnecessary new taxa. While it would be quite possible to divide existing species of Semicytherura into shape or ornamental 'genera', it would not be possible - since many of the ornamental morphotypes are both world-wide and widely distributed stratigraphically - to demonstrate a greater genetic relationship between species of one particular ornamental morphotype than between species of different morphotypes. Indeed, it seems that apparently nonrelated iterative species of various morphotypes have occurred throughout the geographical and stratigraphical (Upper Cretaceous to Recent) range of the genus. In our opinion, the unifying features, the wide anterior fused zone with its characteristic radial pore canals and the internally inflected posterior inner margin/line of concrescence are typical of the genus Semicytherura. On the other hand, when Yamada et al. (2004, 2005a) studied the ultrastructure of the carapace of some Semicytherura 
species, they noticed that the structure of the calcareous lamella developed inside the carapace differs from the foliated grains of the outer lamella, showing a prismatic structure they termed the 'prismatic layer'. According to Yamaha et al. (2005b), sexual dimorphism in the prismatic layer (lack of, or narrow layer in the female) is recognized in some Semicytherura species, such as Semicytherura slipperi Yamaha et al., 2005b.

Van Morkhoven (1963, p. 349) also suggests that, while he, for the moment, considers Howeiina Hanai, 1957, published in the same year but shortly after Wagner's paper, to be a junior synonym of Semicytherura, 'It may, however, eventually turn out to be a subgenus of Semicytherura'. We have no doubt that Howeiina is a junior synonym of Semicytherura and we would also place Levocytherura, Schornikov, 1969, in synonomy, since there are many other perfectly good species of Semicytherura with their allegedly diagnostic characteristics.

\section{PROBLEMATICAL TAXA}

Three species (and for all we know there may be more) that we prefer to retain in Semicytherura differ from 'normal' species of the genus in that the uniquely irregular course of the posterior inner margin/line of concrescence seems to be sex-linked, since it differs in males and females. The species are: Semicytherura slipperi Yamaha et al., 2005b, S. clavata (Brady, 1880) and $S$. contraria Zhao \& Whatley, 1989. Two of them, S. clavata (Brady, 1880) and S. contraria Zhao \& Whatley, 1989, are the aim of this paper. In both species, the posterior excursion of the inner margin/line of concrescence towards the interior is present only in males. In females of both species, the inner margin/line of concrescence posteriorly is relatively narrow and subparallel to the outer margin. Re-emphasizing that species with similar structures are not necessarily closely related is the fact that $S$. clavata is a sub-Antarctic and southern South West Atlantic species, while $S$. contraria is a living species from Malaysia.

Semicytherura clavata is very feebly ribbed with fine intercostal puncta. Adults range from about to $0.45 \mathrm{~mm}$ to $0.50 \mathrm{~mm}$, with the species occurring in the Falkland Islands (Brady, 1880; Whatley et al., 1988, 1995) and along the coasts of Tierra del Fuego and Argentinian Patagonia north to San Antonio Oeste, Rio Negro Province. It also occurs in the estuary of the Rio de La Plata and on the continental shelf off Buenos Aires Province (Whatley et al., 1988, 1997, 1998). Cusminsky \& Whatley (2000) and Whatley \& Cusminsky (2002) have recorded S. clavata from the Upper Pliocene of a core on the Burdwood Bank, south of the Falkland Islands (Islas Malvinas).

Semicytherura contraria is well illustrated (Zhao \& Whatley, 1989, pl. 1, figs 10-14) and the distinction between the course of the posterior inner margin/line of concrescence of the female (fig. 13) and the male (fig. 14) is very evident. Professor Zhao Quanhong has made available to us the negatives of Zhao \& Whatley's (1989) figures 10-13 from plate 1, which are reproduced here (Pl. 1 figs 4-7). The negative of figure 14 is, unfortunately, missing.

In the case of Semicytherura clavata, Brady's (1880) illustrations (pl. 29, figs 7a-d) do not include an internal view. However, the re-illustration of the type material of the species by Puri \& Hulings (1976, pl. 19, figs 7-10) shows clearly that in the internal view of the female (fig. 10) there is no excursion of the inner lamella/line of concrescence; it is possible to view this using a hand lens in the internal view of the male (fig. 9).

Whatley et al. (1988, pl. 2, figs 6-8) illustrate only an internal male left valve, which shows the posterior extension of the fused zone, but do not comment on the phenomenon. Whatley et al. (1995, pl. 2, fig. 5) figure only a single male left valve in external view from the Falkland Islands, but also fail to comment on the internal characters of the species, as do Whatley et al. (1997, pl. 5, fig. 4), who figure a female in external view from the Patagonian littoral, and Whatley et al. (1998, pl. 2, figs 27, 28), who figure in external view a male and a female specimen from the Argentinian continental shelf.

However, Whatley \& Cusminsky (2002, pl. 2, figs 12-14) figure internal views of a female (fig. 12) and a male (fig. 14), which clearly demonstrate the differences between the inner lamellae of the two sexes. This material is from the Upper Pliocene of the Burdwood Bank and material from this locality is also illustrated herein (P1. 1, figs 1-3).

Whatley \& Cusminsky (2002) comment that:

"This species and one other (Semicytherura contraria Zhao \& Whatley, 1989) from the Recent of Malaysia, are the only species of the genus in which the posterior invagination of the inner lamella and the line of concrescence in present only in the males."

\section{RELATIONSHIPS TO ANGULICYTHERURA}

Schornikov \& Dolgov (1995) erected the new cytherurine genus Angulicytherura for five Recent species from near-shore waters of eastern Kamchatka, the Kurile Islands and Peter the Great Bay in the Russian Pacific and for a species from brackish water on the western coast of Honshu Island, in the Sea of Japan.

Angulicytherura, in common with Semicytherura clavata and $S$. contraria, is characterized by the fact that, as stated by Schornikov \& Dolgov (1995, p. 25) 'the outline of the inner margin of the female shell corresponds to that of Cytherura and of (the) male, to Semicytherura'. This is not strictly true because anteriorly in the male valves of Angulicytherura the inner lamella more closely resembles Cytherura. However, the authors state that their genus differs from both Cytherura and Semicytherura in possessing small vestibula at each end and:

"by the character of the sexual dimorphism of the antenna, particularly the presence of a hypertrophied club-shaped seta on the 3 rd podomere. According to the hinge structure and the presence of 2 furcal setae, the new genus approaches Cytherura, but they differ in the arrangement of mandibular muscle scars and some other features."

While we are not absolutely certain that all valid species of Cytherura are avestibulate, we know of none with vestibula. The senior author is acquainted with more than 100 species of Semicytherura, all of which are avestibulate, and neither $S$. clavata nor $S$. contraria have vestibula. They are not, therefore, members of Angulicytherura, for which genus the presence of vestibula is evidently an important diagnostic character.

In external view all the species of Angulicytherura described by Schornikov \& Dolgov (1995), with the single exception of $A$. 


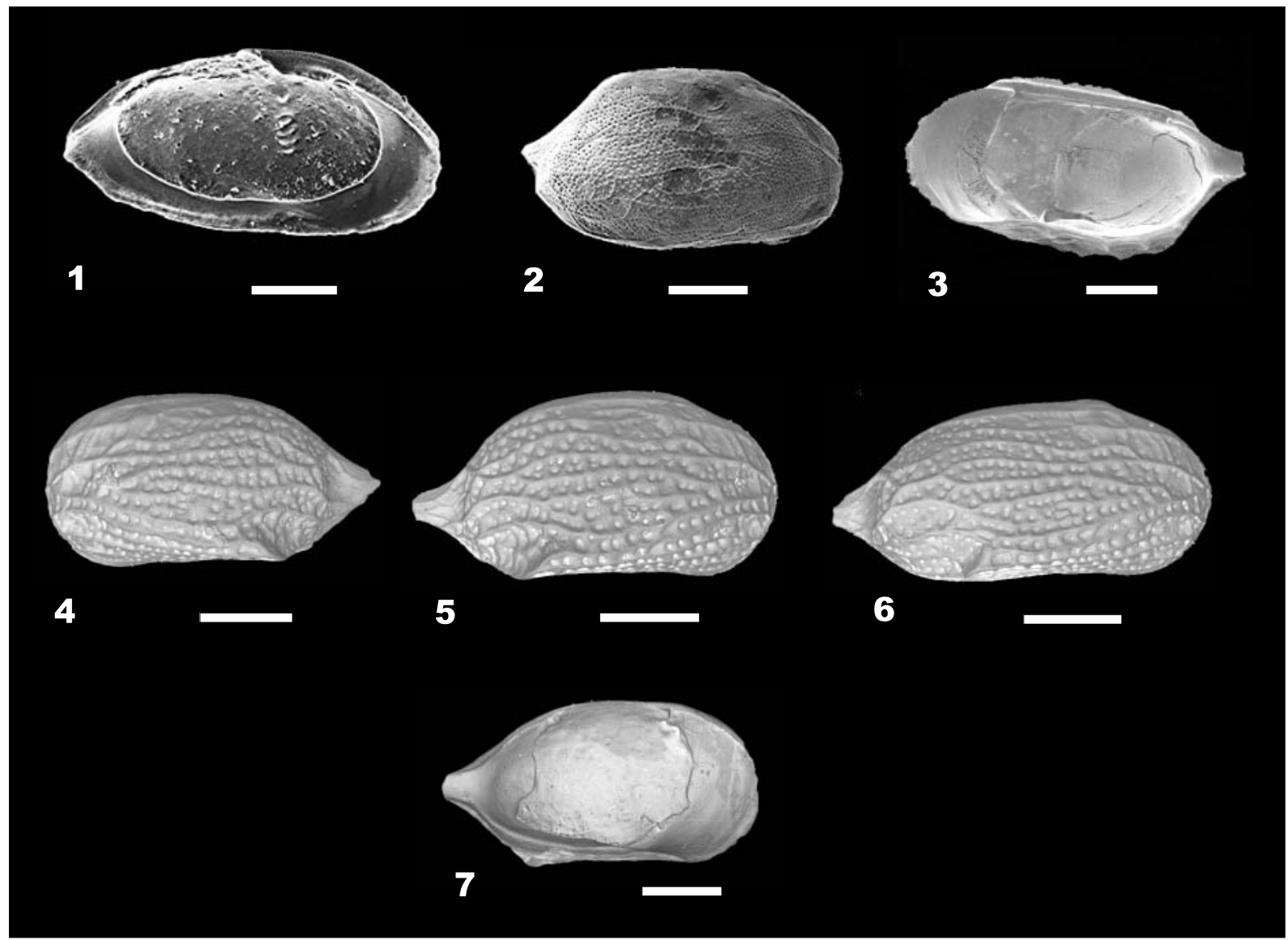

Explanation of Plate 1.

figs 1-3. Semicytherura clavata (Brady, 1880): 1, female left valve, internal view, MLP-Mi 1110; 2, female, right valve, external lateral view, MLP-Mi 1111; 3, male right valve, internal view, MLP-Mi 1113. figs 4-7. Semicytherura contraria Zhao \& Whatley, 1989: 4, female, left valve external lateral view, 1989, 24; 5, female, right valve, external lateral view, 1987, 23; 6, Male, right valve external lateral view, 1987, 26; 7, female, left valve internal lateral view, 1987, 25. Scale bar $100 \mu \mathrm{m}$.

truncata from Peter the Great Bay in the Japan sea, which lacks the typical caudal process, closely resemble Cytherura or many species of Semicytherura. Internally, however, the females of all species, apart from the tiny vestibula at the end margins, are very reminiscent of Cytherura. In the males, however, while the anterior margin is close to that of Cytherura, posteriorly there is a small excursion of the inner margin of the fused zone towards the interior. Not only is this feature much smaller than it is in both sexes of 'normal' Semicytherura, it also extends a much shorter distance towards the interior. A further difference is that this feature in Angulicytherura has a postero-dorsal long axis, while this axis in Semicytherura is usually at or near mid-height.

\section{CONCLUSIONS}

1. Cytherura, Semicytherura and Angulicytherura are separate but related genera.

2. Semicytherura clavata and $S$. contraria only superficially resemble species of Angulicytherura. Their differences are greater than their similarities.

3. Semicytherura clavata and $S$. contraria, despite the close similarity of their sex-linked fused zones, are probably not closely related since they are separated by many thousands of miles, deep ocean basins and the Equator.

4. Although these are the only three known species of Semicytherura in which the generically characteristic posterior inner lamella is present only in males, a new taxon should not be erected to accommodate them. Rather, a common sense approach demands that they should be considered the exception that proves the rule. That is, that they represent nothing more than unusual species of Semicytherura.

\section{ACKNOWLEGEMENTS}

Both authors gratefully acknowledge the International Agreement of Cooperation between CONICET (Consejo Nacional de Investigaciones Científicas y Técnicas de Argentina) and the Royal Society, which has permitted them to study in PROGEBA and in the Institute of Earth Studies, Aberystwyth respectively. Thanks go to Professor Zhao Quanhong, who made available the negatives of Semicytherura contraria, and Victoria Amos and María Adela Cañás for the artwork. Gabriela Cusminsky thanks the Hydrographic Service and the late Dra Alwine Bertels for introducing her to micropaleontology. Robin Whatley has affection for the way he has always 
been treated in Argentina This work is a contribution to the projects PICT 26057, PIP-CONICET 00819 and UN Comahue 04/B001. The paper has also benefited from the comments of D. Horne, N. Ainsworth and J. Gregory.

\section{Manuscript received 4 August 2008 Manuscript accepted 11 December 2009}

\section{REFERENCES}

Barbieto-González, P.J. 1971. Die ostracoden des kustenbreiches von Naxos (Griechenland) und ihre lebensbereiche. Mitteilungen aus dem Hamburgischen Zoologischen Museum und Institut, 67: 255-326.

Brady, G.S. 1880. Report on the Ostracoda dredged by the H.M.S. Challenger during the years 1873-1876. Reports of the Voyage of the Challenger, Zoology, London, 1: 1-184.

Coryell, H.N. \& Fields, S. 1937. A Gatun ostracode fauna from Cativa. Panamá. American Museum Novitares, 956: 1-18.

Cusminsky, G.C. \& Whatley, R.C. 2000. Ostrácodos de un testigo del Banco Burdwood, Océano Atlánticos Sudoccidental austral. Ameghiniana, 37(2): 205-212.

Elofson, O. 1941. Zur Kenntnis der marinen Ostracoden Schwedent, it besonderer Berücksichtigung des Skagerraks. Zoologiska Bidrag fran Uppsala, 19: 215-534.

Hanai, T. 1957. Studies on the Ostracoda from Japan. III. Subfamilies Cytherurinae G. W. Müller (emend. G. O. Sars 1925) and Cytheropterinae n. subfamily. Journal of the Faculty of Science, Imperial University, Tokyo Section II, 11(1): 11-36.

Kempf, E.K. 1986a. Index and Bibliography of Marine Ostracoda. Part 1. Index A. Geologisches Institut der Universitaet zu Koeln. S. Vereoff, 50: 762pp.

Kempf, E.K. 1986b. Index and Bibliography of Marine Ostracoda. Part 2. Index B. Geologisches Institut der Universitaet zu Koeln. S. Vereoff, 51: 712pp.

Kempf, E.K. 1987. Index and Bibliography of Marine Ostracoda. Part 3. Index C. Geologisches Institut der Universitaet zu Koeln S. - Vereoff, 52: $771 \mathrm{pp}$.

Kempf, E.K. 1988. Index and Bibliography of Marine Ostracoda. Part 4. Bibliography A. Geologisches Institut der Universitaet zu Koeln. S. Vereoff, 53: 454pp.

Kempf, E.K. 1995. Index and Bibliography of Marine Ostracoda. Part 6. Index A. Suppl. 1. Sonderversoeffenstlichungen, Geologisches Institut der Universitaet zu Koeln, 100: 1-244.

Kempf, E.K. 1996. Index and Bibliography of Marine Ostracoda. Part 9. Bibliography C. Suppl. 1. Sonderversoeffenstlichungen. Geologisches Institut der Universitaet zu Koeln, 103: 1-198.

Müller, G.W. 1894. Die Ostracoden des Golfes von Neapel un der angrenzenden Meeresabschnitte. Naples Sta Zool. Fauna Flora. Geolfes Neapel, Monographie, 31: 1-404.
Puri, H.S. \& Hulings, N.C. 1976. Designation of lectotypes of some ostracods from the Challenger Expedition. Bulletin of the British Museum (Natural History), Zoology, 29(5): 249-316.

Sars, G.O. 1866. Oversigt af Norges marine Ostracoder. Christiania Videnskaba-Selskabs Forhandlinger, 7: 1-130.

Schornikov, E.I. 1969. A new family of Ostracoda from the supratidal zone of Kuril Islands. Zoologickeskii Zhurnal, 48: 494-498.

Schornikov, E.I. \& Dolgov, G.V. 1995. Angulicytherura gen. n. - A new ostracod genus of the family Cytheruridae from Far eastern seas. Russian Journal of Marine Biology, 21(1): 34-31.

Van Morkhoven, F.P.C.M. 1963. Post-Palaeozoic Ostracoda, Vol. 2. Elsevier, Amsterdam, 478pp.

Wagner, C.W. 1957. Sur les Ostracodes du Quaternaire Récent des Pays-bas et leur utilisation dans l'etude géologique des dépôts Holocenes. Mouton \& Co, The Hague, 259pp.

Whatley, R.C. 1970. Scottish Callovian and Oxfordian ostracoda. Bulletin British Museum (Natural History) Geology, 19(6): 297-358.

Whatley, R.C. \& Boomer, I. 2000. Systematic review and evolution of the early Cytheruridae. Journal of Micropalaeontology, 19(2): 139152.

Whatley, R.C. \& Cusminsky, G. 2002. Upper Pliocene Ostracoda from the Burdwood Bank, SW Atlantic. Revista Española de Micropaleontología, 34(1): 53-80.

Whatley, R.C., Chadwick, J., Coxill, D. \& Toy, N. 1988. The ostracod family Cytheruridae from the Antarctic and South-West Atlantic. Revista Española de Micropaleontología, 20: 171-203.

Whatley, R.C., Toy, N., Moguilevsky, A. \& Coxill, D. 1995. Ostracoda from the South West Atlantic. Part 1. The Falkland Islands. Revista Española de Micropaleontología, 27(1):17-38.

Whatley, R.C., Toy, N., Chadwick, J.M. \& Ramos, M.I.F. 1997. Ostracoda from the South West Atlantic Part II. The littoral fauna from between Tierra del Fuego and the Río de La Plata. Revista Española de Micropaleontología, 29(2): 5-83.

Whatley, R.C., Moguilevsky, A., Chadwick, J., Toy, N. \& Ramos, M.I.F. 1998. Ostracoda from the South West Atlantic. Part III The Argentinian, Uruguayan and Southern Brazilian Continental Shelf. Revista Española de Micropaleontología, 30(2): 89-116.

Yamada, S., Tsukagoshi, A. \& Ikeya, N. 2004. Ultrastructure of the carapace in some Semicytherura species (Ostracoda: Crustacea). Micropaleontology, 50: 381-389.

Yamada, S., Tsukagoshi, A. \& Ikeya, N. 2005a. Carapace formation of the podocopid ostracode Semicytherura species (Crustacea: Ostracoda). Lethaia, 38: 323-332.

Yamada, S., Tsukagoshi, A. \& Ikeya, N. 2005b. Taxonomy, morphology and speciation of the Semicytherura henryhowei group (Crustacea: Ostracoda) Hydrobiologia, 538: 243-265.

Zhao, Q. \& Whatley, R.C. 1989. Recent podocopid Ostracoda of the Sedili River and Jason Bay, southeastern Malay Peninsula. Micropaleontology, 35(2): 168-187. 